\title{
ANALISIS TIME DEPOSIT MONEY DI INDONESIA
}

\author{
Triyono \\ Fakultas Ekonomi Universitas Muhammadiyah Surakarta \\ E-mail: triums@yahoo.com.sg
}

\begin{abstract}
Time deposit is one of the expected banking product can gather people money significantly. Gathered people money can be used to fulfill attainment of economy growth target. In reality, position of time deposit often fluctuate caused many economic factors.

This research aim is to examine economic factors which theoretically influence time deposit. The factors are inflation rate, national income, deposit rate, Rupiah exchange rate to dollar and invesment value. Result of the research indicates variables that influence position of time deposit are inflation and time deposit one year before.
\end{abstract}

Keywords: time deposit, inflation, development

\section{PENDAHULUAN}

Perbankan sebagai lembaga usaha yang bergerak dalam bidang keuangan membuka kesempatan yang luas kepada masyarakat, dan diberi kepercayaan untuk mengalokasikan dana yang terhimpun secara efisien dan efektif. Sebagai agent of intermediary perbankan harus makin mampu berperan sebagai penggerak dan mobilisasi dana masyarakat yang efektif dan sebagai penyalur yang cermat dari dana tersebut untuk pembiayaan yang produktif. Sebagai agent of development perbankan harus meningkatkan fungsi dan peranan agar mampu menampung dan menyalurkan aspirasi serta minat masyarakat untuk berperan aktif dalam pembangunan.

Deposito merupakan bagian dari tabungan nasional. Sebagai alat penghimpun dana, keunggulan deposito adalah menawar- kan suku bunga yang relatif lebih tinggi dibandingkan dengan produk perbankan lain, hal tersebut diharapkan sebagai penarik minat para nasabah untuk mendepositokan uangnya.

Modal pembangunan yang berasal dari dalam negeri biasanya dihimpun dari dana masyarakat. Dana yang dihimpun bank biasanya dalam bentuk giro, deposito, dan tabungan. Guna mendukung kinerja perbankan, pemerintah telah banyak mengeluarkan kebijakan di bidang keuangan. Paket 1 Juni 1983 (PAK JUN '83) dapat dikatakan sebagai kebijakan liberalisasi perbankan. Bank dapat menentukan tingkat bunga yang dianggap memadai dengan mempertimbangkan berbagai faktor antara lain perbedaan tingkat inflasi antar negara, disparitas (overvalue) Rupiah terhadap dollar AS dengan mata uang negara lain, perbedaan tingkat 
suku bunga dalam negeri dengan suku bunga di pasaran internasional, serta meningkatkan pendapatan nasional baik melalui peningkatan ekspor maupun dengan peningkatan investasi. Dengan berhasilnya liberalisasi perbankan maka arus pengalihan Rupiah ke mata uang asing dapat dibendung. Dalam lingkup yang lebih luas keberhasilan liberalisasi perbankan dipengaruhi oleh sistem dana masyarakat untuk tujuan inverstasi jangka panjang dan peningkatan ekspor.

Pada tahun 1998, disusul dengan dikeluarkannya paket Oktober 1998 (Pakto '88). Dalam paket ini pada intinya pemerintah menjamin dana masyarakat yang ada di bank secara preventif dan memberi kesempatan yang sama antara bank swasta dan pemerintah untuk dapat bersaing dan menghimpun dana masyarakat. Hasil kebijakan tersebut cukup memuaskan, sebagaimana terlihat dari meningkatnya dana deposito, giro dan tabungan masyarakat secara pesat Rp 15.498,2 milyar pada tahun 1984, meningkat menjadi $\mathrm{Rp} 223.727,8$ milyar pada tahun 1995 dan pada tahun 2002 menjadi Rp 719.342 milyar.

Di Indonesia, terjadi fluktuasi posisi deposito sehingga tingkat pendanaan yang diperlukan untuk pembangunan mengalami turun naik yang berakibat belum cukup memadai pencapaian target pertumbuhan ekonomi.

Pokok permasalahan pada penelitian dapat dirumuskan sebagai berikut: Apakah pendapatan nasional, suku bunga deposito, tingkat inflasi, nilai tukar Rupiah terhadap dollar, investasi, berpengaruh terhadap penghimpunan deposito berjangka pada bank umum di Indonesia?, Seberapa besar variabel-variabel tersebut mempengaruhi deposito berjangka pada bank umum di Indonesia?

\section{TINJAUAN TEORI DAN PENELITIAN TERDAHULU}

\section{Deposito Berjangka}

Deposito berjangka adalah simpanan yang penarikannya hanya dilakukan pada waktu tertentu menurut perjanjian antara penabung dengan pihak bank yang bersangkutan. Deposito berjangka merupakan simpanan masyarakat yang penarikannya dapat dilakukan setelah jangka waktu yang disetujui berakhir.

Menurut UU No. 10 tahun 1998, Deposito Berjangka (Time Deposit) adalah simpanan pihak ketiga yang penarikannya dilakukan setelah waktu yang ditentukan berakhir, itu berarti bank mempunyai kepastian bahwa selama jangka waktu tersebut uang simpanan akan menetap di bank, sehingga bank akan dapat menggunakan dana tersebut untuk dikelola/disalurkan kepada masyarakat.

Beberapa macam deposito yang dikenal, yaitu:

1) Time Deposit (Deposito Berjangka), yaitu deposito yang terikat oleh waktu yang telah ditentukan. Apabila waktu yang telah ditentukan habis, maka deposan dapat mengambil langkahlangkah:

a) Menarik simpanan deposito berjangka itu dari bank.

b) Memperpanjang simpanan deposito berjangka itu dengan suatu periode tertentu yang diinginkan.

2) Deposit on Call, dimaksudkan uang simpanan tetap berada di bank selama belum dibutuhkan oleh pemiliknya. 
Apabila penyimpan menarik simpanannya, maka terlebih dahulu perlu dan harus memberitahukan kepada bank.

3) Demand Deposit (Rekening Koran Giro), penyimpan dapat menyimpan atau menarik dananya dari bank setiap saat yang dikehendaki.

Pada umumnya gerakan deposito berjangka jika ditinjau dari segi bank, maka aktivitasnya adalah merupakan salah satu kegiatan untuk mengumpulkan dana (uang) yang berlebih yang terdapat di dalam masyarakat. Deposito berjangka ditinjau dari segi dana yang terdapat di dalam suatu negara, maka tujuan utamanya adalah untuk lebih memanfaatkan perkreditan serta danadana dari kalangan masyarakat untuk mensukseskan stabilisasi dan pembangunan non ekonomi.

Untuk lebih menggalakkan gerakan deposito berjangka dalam mencapai tujuan yang dikehendaki, maka kepada para konsumen diberikan daya penarik antara lain:

1) Deposan dapat menarik simpanannya/ menguangkan bilyet depositonya di bank setiap saat, walaupun belum sampai pada jatuh tempo yang diinginkan.

2) Pengambilan dana kepada para deposan dijamin oleh Bank Indonesia sebagai Bank Sentral.

3) Bunga deposito berjangka bebas dari segala macam pajak.

4) Pemerintah tidak akan mengusut (untuk keperluan pajak) mengenai asal-usul uang yang didepositokan.

Dengan turun tangannya pemerintah (dalam hal ini melalui BI) kepentingan para deposan benar-benar mendapat perhatian dan memperoleh jaminan untuk setiap saat dapat menarik dananya yang disimpan di dalam deposito berjangka itu.

\section{Pendapatan Nasional}

Perhitungan pendapatan nasional dapat dilakukan dengan tiga cara yaitu dengan cara pendapatan, cara pengeluaran, dan cara produksi. Dengan cara pendapatan yang dihitung adalah pendapatan atas faktor-faktor produksi yang digunakan dalam menghasilkan barang dan jasa. Dengan cara produksi yang dihitung adalah nilai produksi yang diciptakan oleh faktor-faktor yang dihasilkan oleh suatu negara. Sedangkan cara pengeluaran adalah menentukan pendapatan nasional dengan jumlah seluruh pengeluaran yang terdiri dari konsumen rumah tangga. Pengeluaran ini dapat diformulasikan sebagai berikut:

$\mathrm{Y}=\mathrm{C}+\mathrm{I}+\mathrm{G}+(\mathrm{X}+\mathrm{M})$

dimana:

Y : Pendapatan Nasional

C : Konsumsi Rumah Tangga

I : Investasi

$\mathrm{G}$ : Pengeluaran Pemerintah

$\mathrm{X}$ : Ekspor

$\mathrm{M}$ : Impor

Perubahan pendapatan nasional dari tahun ke tahun juga disebabkan oleh perubahan harga-harga untuk mengetahui suatu perubahan yang sebenamya terjadi dalam kegiatan ekonomi. Untuk itu pengaruh perubahan harga-harga terhadap nilai pendapatan nasional harus dihilangkan dengan cara menghitung pendapatan nasional menurut harga yang berlaku. 
Untuk menghitung pendapatan nasional riil sebagai alat dalam mengukur pertumbuhan ekonomi, terlebih dahlu harus dihilangkan pengaruh perubahan harga yang terjadi dari tahun yang satu dengan tahun yang lainnya menurut harga yang berlaku sehingga terbentuk angka agregat ekonomi menurut harga konstan. Dalam hal ini ada 3 metode untuk mengubah angka menurut harga-harga berlaku menjadi harga konstan, yaitu metode revaluasi yang dilakukan dengan cara menilai produksi masing-masing tahun dengan menggunakan harga tahun tertentu yang dijadikan sebagai tahun dasar. Metode ekstrapolasi dilakukan dengan cara memperbaharui (updating) nilai tahun dasar sesuai dengan indeks produksi atau tingkat pertumbuhan riil dari tahun sebelumnya, sedangkan metode deflasi dilakukan dengan cara membagi nilai masing-masing tahun dengan harga relatif yang sesuai (Dumairy, 1997: 38).

Menghitung pendapatan nasional riil merupakan langkah yang selalu dijalankan dalam kegiatan menghitung pendapatan nasional dari berbagai negara. Salah satu tujuan dalam menghitung pertumbuhan suatu negara yang berlaku dari tahun ke tahun yang diperoleh dari perhitungan pendapatan nasional riil dengan produk Domestik Bruto yang telah disesuaikan menurut harga konstan.

\section{Tingkat Suku Bunga}

Tingkat suku bunga merupakan balas jasa untuk melepaskan likuiditas selama kurun waktu tertentu karena tingkat bunga merupakan perkembangan antara sejumlah uang dengan apa yang diperoleh jika pengendalian terhadap uang yang dilepaskan untuk ditukar dengan hutang jangka tertentu.
Apabila tingkat bunga rendah maka investasi yang tepat bagi masyarakat tidak dalam bentuk tabungan, tetapi jika suku bunga tinggi maka masyarakat lebih baik berinvestasi dalam bentuk tabungan.

Menurut pendapat kaum klasik, suku bunga ditentukan oleh persilangan antara kurva permintaan investasi dan kurva tabungan (Boediono, 1985) dari proses tawar menawar penabung dengan investor akan menghasilkan suku bunga kesepakatan dan keseimbangan.

Tingkat bunga merupakan harga dari penggunaan uang dalam waktu tertentu yang didasarkan pada permintaan dan penawaran akan uang. Hasrat untuk menabung timbul apabila diberikan bunga sebagai imbalan.

Kebutuhan penentuan tingkat suku bunga deposito serta tabungan pada bankbank pemerintah merupakan salah satu inti kebijakan pengerahan dan guna membiayai pembangunan dana untuk menyerap uang yang tidak aktif dari penggunaan spekulatif dan tidak produktif di masa inflasi. Sehingga untuk merangsang agar sebagian dana masuk ke dalam negara terutama dana perbankannya meningkat maka suku bunga deposito dinaikkan begitu pula sebaliknya, jika suku bunga depositonya rendah maka akan mengurangi gairah penabung untuk mendepositkan/menyimpannya dalam bentuk tabanas dan taska (Boediono, 1988 : 75)

\section{Inflasi}

Inflasi dikategorikan menjadi dua macam:

\section{a. Inflasi yang tidak diantisipasi}

Inflasi pada keadaan ini akan mengikis nilai riil dari posisi nominal kreditur. Kreditur akan dirugikan saat inflasi lebih besar dari dugaan. Sedangkan debitur 
akan dirugikan dengan inflasi yang lebih lecil dari perkiraan.

\section{b. Inflasi yang diantisipasi}

Kreditur dan debitur mengantisipasi inflasi mendatang dengan suku bunga sebagai harapan inflasi (expectation). Suku bunga riil saat ditetapkan (exant) berdasarkan:

$\mathrm{R}=\mathrm{t}-\pi^{\mathrm{c}}$

Sedangkan suku bunga riil saat bereaksi (expost) adalah:

$\mathrm{R}=\mathrm{t}-\pi$

Persamaan tersebut dapat diaplikasikan saat uang riil disamakan dengan permintaan uang yang dipengaruhi oleh suku bunga dan pendapatan, yaitu :

$\mathrm{M} / \mathrm{p}=\mathrm{L}(\mathrm{t}, \mathrm{Y})$

$\mathrm{M} / \mathrm{p}=\mathrm{L}\left(\mathrm{r}+\pi^{\mathrm{c}} . \mathrm{Y}\right)$

dimana:

$r$ : Suku bunga riil

$\mathrm{t}$ : Suku bunga nominal

$\pi^{\mathrm{c}} \quad$ : Inflasi yang diharapkan (expected inflation)

$\pi \quad$ : Tahun inflasi

$\mathrm{M} / \mathrm{p} \cdot$ : Keseimbangan riil

$\mathrm{Y}$ : Pendapatan

Dengan demikian keseimbangan uang riil akan tergantung pada inflasi yang diharapkan, kenaikan inflasi ini akan menaikkan suku bunga nominal. Sehingga secara langsung menurunkan permintaan uang, karena penawaran uang tetap, nilai suku bunga riil akan naik. (Mankiw, 2000: 161-174). Keadaan tersebut searah dengan penelitian Philip Cagon dari Columbia University (dalam Rodriguez et al. 2001) yang menemukan bahwa harapan inflasi akan menaikkan suku bunga dan keseimbangan uang riil, sehingga inflasi dapat mendorong pertumbuhan uang yang lebih tinggi di masa yang akan datang.

Pertumbuhan uang akan menciptakan permintaan agregat dan harga yang lebih tinggi dalam keadaan yang tidak sebanding dengan jumlah komoditas. Keadaan ini diistilahkan sebagai demand pull inflation. Sebagaimana hukum Say (Say's Law) bahwa penawaran membentuk permintaannya sendiri, maka dibalik demand pull inflation terdapat kenaikan penawaran uang yang sangat cepat (Samuelson \& Nordhaus, 2001: 246)

\section{Investasi}

Pengertian investasi itu sendiri adalah seluruh nilai pembelian atas barang-barang modal (mesin dan peralatan) dan pembelanjaan untuk mendirikan industri (Sukirno, 1980: 71). Sebab dengan adanya investasi berpengaruh terhadap kesempatan kerja dan pendapatan dengan semakin besarnya volume investasi maka dapat menentukan tambahan pendapatan dan tambahan karyawan.

Jika tingkat suku bunga naik maka masyarakat akan cenderung menginvestasikan dananya dalam bentuk tabungan, namun dalam waktu bersamaan anggota masyarakat melakukan investasi semakin berkurang. Demikian pula sebaliknya jika suku bunga turun maka masyarakat cenderung akan lebih banyak melakukan investasi daripada menabung.

\section{Nilai Tukar Rupiah (Kurs)}

Kurs adalah harga mata uang luar negeri dalam satuan harga mata uang domestik. Suatu kenaikan dalam kurs disebut 
depresiasi/penurunan nilai mata uang dalam negeri terhadap mata uang asing dan suatu penurunan dalam kurs disebut apresiasi/ kenaikan dalam nilai mata uang dalam negeri (Salvatore, 1997:49)

Pendapatan lain dikemukakan oleh McEachern (2000:436); Kurs adalah harga mata uang suatu negara diukur dengan mata uang negara lain. Sedangkan menurut Purnomo dan Wahyudi (2003) Kurs adalah perbandingan harga/nilai tukar valuta asing.

Macam-macam kurs yaitu:

a. Kurs Mengambang

Dalam sistem kurs mengambang yang berlaku sejak tahun 1973, kurs ekuilibrium tercipta dari perpotongan antara kurva permintaan dan kurva penawaran agregat dari suatu negara lain/valuta asing.

b. Kurs Spot

Kurs Spot adalah kurs yang digunakan landasan transaksi, jenis transaksi valuta asing yang paling dikenal adalah pembayaran dan penerimaan valuta asing yang terlaksana dalam 2 hari kerja setelah disepakati tersebut periode selama 2 hari kerja tersebut dimaksudkan untuk memberikan instruksi pendebetan dan pengkreditan rekening mereka pada bank-bank yang terkait, baik yang berada di dalam/di luar negeri.

c. Kurs Berjangka

Kurs berjangka adalah kesepakatan yang dicapai pada hari ini untuk membeli sejumlah valuta asing yang penyerahannya dilakukan di masa mendatang berdasarkan tingkat nilai tukar Rupiah (kurs) yang disepakati pada hari ini.

\section{Penelitian Sebelumnya}

Penelitian yang dilakukan Shanti Arditya Brahmanti (2004) menggunakan analisis regresi double log berganda dengan nilai signifikan 0,05 didapatkan hasil bahwa variabel suku bunga deposito, tingkat inflasi, dan total aktifa bank umum selama tahun 1968-2001 memiliki pengaruh yang signifikan terhadap penghimpunan deposito berjangka bank umum. Sedangkan variabel pendapatan nasional tidak memiliki pengaruh yang signifikan terhadap penghimpunan deposito berjangka.

Sedangkan penelitian yang dilakukan oleh Eni Wijayanti (2000) menganalisis faktor-faktor yang mempengaruhi perkembangan deposito berjangka sebelum dan sesudah deregulasi 29 Mei 1993 di Indonesia menggunakan model analisis linier berganda dengan nilai signifikan 0,05 didapatkan hasil bahwa variabel suku bunga deposito produk domestik bruto dan inflasi berpengaruh positif terhadap perkembangan deposito berjangka. Sedangkan deposito berjangka sebelum dan sesudah deregulasi 29 Mei 1993 dari hasil pengolahan data menunjukkan hasil yang tidak sesuai dengan hipotesis yang diharapkan artinya tidak ada perbedaan yang nyata.

Penelitian yang dilakukan oleh Bhakti Artanta (1995) menganalisis faktor-faktor yang mempengaruhi tingkat bunga deposito oleh kelompok bank pemerintah di Indonesia tahun 1978-1993 dimana variabelnya adalah tingkat bunga deposito, pendapatan nasional, jumlah yang beredar, inflasi, dan tingkat bunga luar negeri tahun sebelumnya tidak mempunyai pengaruh yang signifikan terhadap tingkat bunga luar negeri. Kondusifnya investasi di Indonesia. Pada tahun tersebut investasi menurun sebesar $15,72 \%$ 
dari 762.573.306 juta Rupiah menjadi 44.550.627 juta Rupiah. Kemudian mulai pulih kembali pada awal tahun 2001. Angka investasi pada awal tahun sebesar 30400656 juta Rupiah. Pada akhir tahun 2004 menurun sebesar 7,38 dari 25.017.442 juta Rupiah menjadi 20.068.717 juta Rupiah.

\section{METODE PENELITIAN}

\section{Tehnik Pengumpulan Data}

Dalam penelitian ini digunakan teknik pengumpulan data berupa:

1. Studi Pustaka

Mencari literatur berbagai sumber yang berhubungan dengan pokok permasalahan dengan tujuan untuk mengetahui teori yang mendasari penulisan skripsi ini.

2. Studi Lapangan

Mengumpulkan data skunder yang berkaitan dengan topik permasalahan yang diteliti, dimana data dikumpulkan bersumber dari Bank Indonesia.

\section{Definisi Variabel}

a. Variabel Dependen

Deposito berjangka adalah simpanan yang penarikannya hanya dapat dilakukan pada saat waktu tertentu menurut perjanjian antara penabung dengan bank yang bersangkutan, yang diukur dengan milyar Rupiah.

b. Variabel Independen

- Pendapatan Nasional

Pendapatan Nasional dalam penelitian ini adalah pokok nasional netto atas dasar biaya produksi berdasarkan harga konstan tahun 1993, yang diukur dalam milyar Rupiah (Wijaya, 1999:62)
- Suku Bunga Deposito

Adalah tingkat suku bunga yang harus dibayar oleh peminjam atau debitur. Data suku bunga yang dipakai adalah suku bunga deposito pada bank pemerintah 12 bulan dalam persen per tahun, yang diukur dalam persen per tahun.

- Tingkat Inflasi

Merupakan kecenderungan kenaikan harga-harga barang jasa secara umum dalam jangka waktu relatif lama, dinyatakan dalam satuan persen per tahun.

- Nilai Tukar Rupiah

Merupakan permintaan yang muncul dari kebutuhan untuk mempertukarkan mata uang domestik ke dalam mata uang asing, dinyatakan dalam $\mathrm{Rp} /$ dollar. (Nopirin: 1997 : 137)

- Investasi (PMA)

Penanaman modal yang dilakukan oleh pihak swasta/sektor luar negeri yang terbentuk dalam modal domestik bruto termasuk di dalamnya perubahan stok. Dinyatakan dalam dollar.

\section{Analisis Data}

Data dalam penelitian ini akan dianalisis dengan model PAM (Partial Adjustment Model) yang mempunyai model jangka panjang sebagai berikut: (Gujarati, 1999: 242)

$$
\begin{aligned}
Y_{t}= & \beta_{0}+\beta_{1} X_{1}+\beta_{2} X_{2}+\beta_{3} X_{3}+\beta_{4} X_{4}+ \\
& \beta_{5} X_{5}+U_{t}
\end{aligned}
$$

Karena Deposito Berjangka tidak hanya dipengaruhi oleh kelima variabel bebas tersebut, maka variabel lainnya disesuaikan dengan adjustment coefficient, sebagai berikut: 
$Y_{t}-Y_{t-1}=\delta\left(Y_{t}-Y_{t-1}\right)$

Sehingga didapatkan persamaan PAM jangka pendek sebagai berikut:

$$
\begin{aligned}
Y_{t}= & \beta_{0}+\beta_{1} X_{1}+\beta_{2} X_{2}+\beta_{3} X_{3}+\beta_{4} X_{4}+ \\
& \beta_{5} X_{5}+(1-\delta) Y_{t-1}+\delta U_{t}
\end{aligned}
$$

dimana:

$Y_{t}$ : Deposito Berjangka

$X_{1}$ : Pendapatan Nasional

$\mathrm{X}_{2}$ : Suku Bunga Deposito

$X_{3}$ : Tingkat Inflasi

$\mathrm{X}_{4}$ : Nilai Tukar Rupiah

$\mathrm{X}_{5}$ : Investasi

$\beta_{0}$ : Konstanta

$\beta_{1}-\beta_{5}$ : Parameter model/Koefisien regresi

$\delta$ : Koefisien Penyesuaian, $0<\delta<1$

Ut : Variabel Pengganggu

$\mathrm{Y}_{\mathrm{t}-\mathrm{I}}$ : Deposito Berjangka tahun sebelumnya

Hasil analisis tersebut akan diuji keakuratannya dengan beberapa pengujian, yaitu:

1) Pengujian asumsi klasik

a. Autokorelasi

Autokorelasi terjadi apabila nilai varian masa lalu memiliki pengaruh terhadap nilai varian masa kini atau mendatang

b. Multikolinieritas

Multikolinieritas muncul jika terdapat hubungan yang sempurna atau pasti di antara beberapa variabel atau semua variabel independen dalam model.

c. Heteroskedastisitas

Heteroskedastisitas terjadi jika varian dari residual model yang diamati tidak konstan seiring dengan berubahnya nilai variabel independen. (Gujarati, 1995:61)

\section{2) Kriteria statistik}

Uji ini untuk menilai Goodnes of Fit yang terdiri dari:

a. Uji $t$ (Significant Parameter Individual) Uji statistik $t$ untuk mengetahui besar pengaruh suatu variabel penjelas secara individual dalam menerangkan variasi terikat. (Kuncoro, 2001:97)

\section{b. Uji F (Significant Simultaneously)}

Uji untuk mengetahui ada tidaknya pengaruh secara bersama dari semua variabel bebas dalam model terhadap variabel terikat. (Kuncoro, 2001:98)

\section{c. $R^{2}$ (Koefisien Determinasi)}

Koefisien ini untuk mengetahui kemampuan model dalam menerangkan variasi variabel terikat (Kuncoro, 2001:100)

\section{PEMBAHASAN}

Secara statistik, tingkat dan arah ketergantungan variabel terikat terhadap masing-masing variabel bebas dalam penelitian ini dianalisis dengan model PAM yang terlihat pada tabel 1.

Tabel 1. Hasil Analisis PAM

\begin{tabular}{crc}
\hline Variabel & Koefisien & T - statistik \\
\hline$C$ & 1.085780 & 0.308434 \\
$X_{1}$ & -0.039508 & -0.115946 \\
$X_{2}$ & 0.000249 & 0.070792 \\
$X_{3}$ & 0.013185 & 3.196875 \\
$X_{4}$ & 0.0074007 & 0.824431 \\
$X_{5}$ & -0.002541 & -0.069658 \\
$Y(-1)$ & 0.886420 & 8.621595 \\
\hline$R^{2}$ & 0.988126 & \\
${ }^{*} R^{2}$ & 0.986147 & \\
$F$ - statistik & 499.3059 & \\
\hline
\end{tabular}

Sumber: Hasil Olahan Data Eviews

Untuk mendapatkan model jangka panjang dilakukan pembagian antara nilai 
koefisien jangka pendek dengan nilai koefisien penyesuaian (1- $\delta$ ) dan menghilangkan variabel $\mathrm{Y}(-1)$. Nilai koefisien tersebut sebesar 1-0.886420 - 0.11358 sehingga didapatkan persamaan sebagai berikut:

$$
\begin{aligned}
Y= & 9.559605-0.347843 X_{1}+0.002192 X_{2}+ \\
& 0.1160855 X_{3}-0.006646 X_{4}- \\
& 0.022371 X_{5}+7.804367 Y_{t-1}+U_{t}
\end{aligned}
$$

* Signifikan pada $1 \%$

Untuk mengidentifikasi permasalahan suatu model dalam mengestimasi data dilakukan pengujian asumsi klasik. Sedangkan untuk mengetahui ketepatan fungsi regresi dalam menaksir nilai aktual dapat diukur dengan uji statistik.

\section{Uji Validitas Asumsi Klasik}

a. Uji Autokorelasi dengan uji Breusch Godfrey

Dengan $\alpha=0,05$ diperoleh $\mathrm{X}^{2}$ tabel $=$ 7,81473 nilai $X^{2}$ hitung $=14,05188>\mathrm{X} 2$ tabel $=7,81473$, maka Ho ditolak sehingga dapat simpulkan bahwa terdapat masalah autokorelasi dalam model.

b. Uji Multikolinieritas

Untuk menunjukkan ada tidaknya hubungan sempurna antar beberapa variabel independen dalam penelitian ini digunakan uji Klein. Di mana jika $\mathrm{R}^{2 *}<\mathrm{R}^{2}$, maka tidak terjadi multikolinieritas. Demikian pula sebaliknya. Keadaan tersebut akan ditunjukkan pada tabel 2.

c. Uji Heteroskedastisitas

Dalam penelitian ini menggunakan uji White. Nilai $\mathrm{X}^{2}=32.904632>\mathrm{X}_{\text {tabel }}=$ 19.6751 maka Ho ditolak sehingga dapat disimpulkan bahwa terdapat masalah heteroskedastisitas dalam model.
Tabel 2. Uji Multikolinieritas dengan Uji Klein

\begin{tabular}{cccl}
\hline Variabel & $\mathbf{R}^{\mathbf{2}}$ & $\mathbf{R}^{\mathbf{2}}$ & Keterangan \\
\hline $\mathrm{X}_{1}$ & 0.794282 & 0.988126 & $\begin{array}{l}\text { Tidak terjadi } \\
\text { multikolinieritas }\end{array}$ \\
$\mathrm{X}_{2}$ & 0.656373 & 0.988126 & $\begin{array}{l}\text { Tidak terjadi } \\
\text { multikolinieritas }\end{array}$ \\
$\mathrm{X}_{3}$ & 0.693632 & 0.988126 & $\begin{array}{l}\text { Tidak terjadi } \\
\text { multikolinieritas }\end{array}$ \\
$\mathrm{X}_{4}$ & 0.963619 & 0.988126 & $\begin{array}{l}\text { Tidak terjadi } \\
\text { multikolinieritas }\end{array}$ \\
$\mathrm{X}_{5}$ & 0.414475 & 0.988126 & $\begin{array}{l}\text { Tidak terjadi } \\
\text { multikolinieritas } \\
\text { Tidak terjadi } \\
\text { multikolinieritas }\end{array}$ \\
\hline
\end{tabular}

\section{Kriteria Statistik}

Uji ini untuk menilai Goodness of fit yang terdiri dari:

\section{a. Uji t (Significant Parameter Individual)} Uji validitas pengaruh atau t-test digunakan untuk mengetahui apakah variabel penjelas (independen) secara sendiri-sendiri berpengaruh secara signifikan terhadap variabel dependen.

Hipotesis yang digunakan adalah:

Ho : $\beta=0$ (variabel independen ke-1 tidak memiliki pengaruh signifikan terhadap variabel dependen)

Ho : $\boldsymbol{\beta} \neq 0$ (Variabel independen berpengaruh signifikan terhadap variabel dependen)

1) Variabel Pendapatan Nasional $\left(X_{1}\right)$

Dari regresi diketahui bahwa besarnya $t_{\text {hitung }}$ sebesar $-0,115946$ sedangkan $t$ tabel dengan $\alpha=0,05$ sebesar 2,0315; karena $-\mathrm{t}_{\text {tabel }}<\mathbf{t}_{\text {hitung }}<\mathbf{t}_{\text {tabel }}$, maka Ho diterima, berarti variabel Pendapatan Nasional tidak berpengaruh signifikan terhadap Deposito Berjangka pada tingkat signifikan 0,05 
2) Variabel Suku Bunga Deposito

Dari regresi diketahui bahwa besarnya $t_{\text {hitung }}$ sebesar 0,070792 sedangkan $t_{\text {tabei }}$ dengan $\alpha=0,05$ sebesar 2,0315, karena $-\mathrm{t}_{\text {tabel }}<\mathrm{t}_{\text {hitung }}<\mathrm{t}$ tabel, maka Ho diterima, berarti variabel Suku Bunga Deposito tidak berpengaruh signifikan terhadap Deposito Berjangka pada tingkat signifikan 0,05 .

3) Variabel Inflasi

Dari regresi diketahui bahwa besarnya $t_{\text {hitung }}$ sebesar 3,196875 sedangkan $t_{\text {tabel }}$ dengan $\alpha=0,05$ sebesar 2,0315, karena $-\mathrm{t}_{\text {tabel }}<\mathrm{t}_{\text {hitung }}<\mathrm{t}$ tabel, maka Ho, berarti variabel inflasi berpengaruh signifikan terhadap deposito berjangka pada tingkat signifikan 0,05 .

4) Variabel Kurs

Dari regresi diketahui bahwa besarnya $t_{\text {hitung }}$ sebesar 0,824431 sedangkan $t_{\text {tabel }}$ dengan $\alpha=0,05$ sebesar 2,0315, karena $-\mathrm{t}_{\text {tabel }}<\mathrm{t}_{\text {hitung }}<\mathrm{t}_{\text {tabel }}$, maka Ho diterima, berarti variabel Kurs berpengaruh signifikan terhadap Deposito Berjangka pada tingkat signifikan 0,05

5) Variabel Penanaman Modal

Dari regresi diketahui bahwa besarnya $t_{\text {hitung }}$ sebesar 0,069658 sedangkan $t_{\text {tabel }}$ dengan $\alpha=0,05$ sebesar 2,0315, karena $-\mathrm{t}_{\text {tabel }}<\mathrm{t}_{\text {hitung }}<\mathrm{t}_{\text {tabel }}$, maka Ho diterima, berarti variabel Penanaman Modal Asing tidak berpengaruh signifikan terhadap Deposito Berjangka pada tingkat signifikan 0,05 .

6) Variabel Deposito Berjangka Tahun Sebelumnya

Dari regresi diketahui bahwa besarnya $t_{\text {hitung }}$ sebesar 8,621595 sedangkan $t_{\text {tabei }}$ dengan $\alpha=0,05$ sebesar 2,0315, karena $-t_{\text {tabel }}<t_{\text {hitung }}<t_{\text {tabel }}$, maka Ho ditolak, berarti Variabel Deposito Berjangka tahun sebelumnya berpengaruh signifikan terhadap Deposito Berjangka pada tingkat signifikan 0,05 .

\section{b. Uji F (Signifikan Simultan)}

Uji ini digunakan untuk mengetahui pengaruh dari variabel independen terhadap variabel dependen secara bersama-sama.

Nilai $\mathrm{F}_{\text {hitung }}=499,3059>\mathrm{F}_{\text {tabel }}=2,43$, maka Ho ditolak sehingga dapat disimpulkan bahwa ada pengaruh yang signifikan antara variabel-variabel dependen dengan variabel independen.

\section{c. $\mathbf{U j i} \mathbf{R}^{2}$}

Hasil regresi menujukkan $\mathrm{R}^{2}$ adalah 0.988126 atau $98.8126 \%$. Hal ini berarti 98.8126 variabel deposito berjangka dapat dijelaskan oleh variabel himpunan bebas. Sisanya $1.1874 \%$ dijelaskan oleh variabel lain di luar yang terangkum dalam kesalahan model.

\section{Interpretasi Ekonomi}

Koefisien regresi-regresi dalam jangka panjang dan jangka pendek adalah sebagai berikut:

\section{Pendapatan Nasional $\left(\mathrm{X}_{\mathrm{l}}\right)$}

Pada tingkat kepercayaan 95\% koefisien Pendapatan Nasional untuk jangka pendek sebesar -0,039508, dimana jika Pendapatan Naisonal naik satu juta Rupiah, maka Deposito Berjangka turun sebesar 0,039508 juta Rupiah. Sedangkan untuk jangka panjang sebesar 0,347843 dimana jika Pendapatan Nasional naik satu juta Rupiah, maka Deposito Berjangka turun sebesar 0,347843 Rupiah. 
2. Suku Bunga Deposito $\left(\mathrm{X}_{2}\right)$

Pada tingkat kepercayaan 95\%, koefisien suku bunga kredit untuk jangka pendek sebesar 0,000249 persen, dimana jika Suku Bunga Deposito naik satu persen maka deposito berjangka naik sebesar 0.000249 juta Rupiah. Sedangkan untuk jangka panjang sebesar 0.002192 dimana jika suku bunga deposito naik satu persen, maka deposito berjangka naik sebesar 0.002192 juta Rupiah.

\section{Nilai Tukar Valuta Asing $\left(\mathrm{X}_{4}\right)$}

Pada tingkat kepercayaan 95\%, koefisien Nilai Tukar Valuta Asing untuk jangka pendek sebesar 0,074007, dimana jika Nilai Tukar Valuta Asing naik sebesar 0.74007 juta Rupiah. Sedangkan untuk jangka panjang sebesar 0.006646 dimana jika Nilai Tukar Valuta Asing naik satu juta Rupiah, maka deposito berjangka naik sebesar 0.006646 juta Rupiah.

\section{Penanaman Modal Asing}

Pada tingkat kepercayaan 95\%, koefisien Penanaman Modal Asing untuk jagka pendek sebesar -0.002541, dimana jika Penanaman Modal Asing naik sebesar satu juta dolar, maka deposito berjangka sebesar 0.002541 juta Rupiah, sedangkan untuk jangka panjang sebesar 0.022371, dimana jika Penanaman Modal Asing satu naik satu juta dolar, maka deposito berjangka turun sebesar 0.022371 juta Rupiah.

\section{KESIMPULAN}

1) Variabel pendapatan nasional, suku bunga deposito, nilai tukar valuta asing, dan penanaman modal asing tidak mempunyai pengaruh signifikan terhadap deposito berjangka.
2) Sedangkan variabel inflasi dan deposito berjangka tahun sebelumnya mempunyai pengaruh yang signifikan terhadap deposito berjangka Bank Umum. Hal ini dapat dijelaskan sebagai berikut:

a) Pada tingkat kepercayaan 95\% koefisien inflasi untuk jangka pendek sebesar 0.013185 , dimana jika inflasi naik satu persen, maka deposito berjangka naik sebesar 0.013185 juta Rupiah. Sedangkan untuk jangka panjang sebesar 0.1160855 dimana jika inflasi naik satu persen, maka deposito berjangka naik sebesar 0.1160855 juta Rupiah.

b) Pada tingkat kepercayaan 95\% koefisien deposito berjangka tahun sebelumnya untuk jangka pendek sebesar 0.886420 juta Rupiah, dimana deposito berjangka tahun sebelumnya naik sebesar 0.886429 juta Rupiah, Sedangkan untuk jangka panjang sebesar 7.8043671 dimana jika deposito berjangka naik sebesar 7.8043671, maka deposito berjangka naik sebesar 7.8043671 juta Rupiah.

3) Hasil analisis terhadap uji asumsi klasik menyatakan tidak ada masalah multikolinieritas tetapi terdapat masalah autokorelasi dan masalah heteroskedastisitas.

4) Hasil regresi menunjukkan nilai $R^{2}$ adalah 0.988126 atau $98.8126 \%$. Hal ini berarti $98.8126 \%$ variabel deposito berjangka dapat dijelaskan oleh variabel himpunan variabel. Sisanya $1.1874 \%$ dijelaskan oleh variabel lain di luar model uang terangkum dalam kesalahan model.

Dengan melihat hasil yang diperoleh dari penelitian yang penulis lakukan, di 
bawah ini dikemukakan beberapa saran sebagai usaha untuk mencapai kondisi perekonomian yang lebih baik, antara lain:

1) Pemerintah diharapkan dapat menciptakan suasana kondusif yang dapat mendukung iklim investasi, khususnya di pasar modal dengan mereduksi hambatan-hambatan investigasi, serta menjaga kestabilan politik dan keamanan.

2) Melalui Otorita Moneter (Bank Indonesia) dalam mengendalikan laju inflasi sebaiknya berupaya mempertahankan likuiditas perekonomian tetap berada dalam batas-batas kebutuhan riil perekonomian. Kondisi ini telah memberikan ruang gerak bagi kebijakan moneter untuk secara bertahap dan konsisten menurunkan suku bunga guna memberikan sinyal positif dalam menjaga ekspektasi pelaku ekonomi terhadap kesinambungan proses pemulihan ekonomi.

3) Bagi penulis lain yang ingin meneliti masalah atau topik yang sama dan berkaitan dengan penelitian ini, maka dalam penelitian selanjutnya dapat mempertimbangkan varisabel lain misalnya: faktor hadiah atau faktor-faktor non ekonomi seperti kondisi sosial ekonomi sehingga diharapkan menambah hasil penelitian lebih baik serta gambaran penelitian yang lebih luas.

\section{DAFTAR PUSTAKA}

Badan Pusat Statistik, 1995-2003. Statistik dalam 50 Tahun Indonesia Merdeka. Surakarta: Badan Pusat Statistik.
Bank Indonesia, Beberapa Edisi Publikasi, Laporan Triwulan Bank Indonesia, Jakarta: Bank Indonesia.

Boediono. 1958. Ekonomi Moneter, Yogyakarta: BPFE UGM.

Gujarati, Damodar, 1997, Ekonomi Dasar. Edisi keempat, Jakarta: Penerbit Erlangga.

Herlambang, Tedy, dkk. 2001. Ekonomi Makro, Teori Analisis dan Kebijakan. Jakarta: PT. Grafindo Pustaka Utama.

Insukindro. 1993. Ekonomi Uang dan Bank: Teori dan Pengalaman di Indonesia. Yogyakarta: BPFE UGM.

Khalwany, Tajul. 2000. Inflasi dan Solusinya. Jakarta: Gramedia Pustaka Utama.

Levi, Maunce, D. 2001. Keuangan Internasional. Alih Bahasa: Handoyo Prasetyo, Yogyakarta: Andi.

Nopirin, 1985, Ekonomi Internasional, Pembayaran Nasional, ,Yogyakarta: Liberty.

Nopirin, 1997, Ekonomi Internasional, Edisi Kedua, Yogyakarta: Liberty.

Nopirin, 1999, Ekonomi Pembayaran Internasional, Edisi Ketiga, Yogyakarta: BPFE UGM.

Setyowati, Eni, dan Soepatini, 2004. Analisis Faktor-faktor yang Mempengaruhi Nilai Tukar Rupiah terhadap Dollar AS dengan Pendekatan Neraca Pembayaran (Pendekatan Engle Granger Error Correction Model) Jurnal Ekonomi Pembangunan FE UMS. Vol. 5 No. 2 147-159

Sukimo, Sadono, 2002. Pengantar Teori Makro Ekonomi Edisi Kedua, Jakarta: PT. Raja Grafindo Persada. 